\title{
Prawda cytatu, czyli o grze alegacjami (na podstawie cyklu Paryskie pasaże Krzysztofa Rutkowskiego)
}

ABSTRACT. Katarzyna Szalewska, Prawda cytatu, czyli o grze alegacjami (na podstawie cyklu "Paryskie pasaże" Krzysztofa Rutkowskiego). The truth of quotation or on an allegations game (based on Krzysztof Rutkowski's cycle Paris Passages)]. "Przestrzenie Teorii" 10. Poznań 2008, Adam Mickiewicz University Press, pp. 105-1 18. ISBN 978-83-232-1946-0. ISSN 1644-6763.

The aim of this article is to consider the relationship between the practice of quoting and truth on the example of Krzysztof Rutkowski's oeuvre. In an obvious way such an interpretation of the subject brings reflections closer to the analyses of intertextuality, however, that which distinguishes intertextual references in the texts discussed from the postmodernistic play with conventions is a different function of the hypotext present through quotations. First of all, it has to validate, i.e. also to axiologically mark the essayist's exposition. The practice of quoting reminds an act of allegation, however, with the reservation that it allows the element of the dialogue. Thus, this article is both an attempt at an analysis of the ways of functioning in the composition of an essay of attempts at imitation as textual strategies as well as - and mostly - combination of the allegation game with the problem of literary truth, the truth of the subject of the essay, but also of the truth expected in the reception by the readers.

Krzysztof Rutkowski to pisarz nad wyraz płodny, nie sposób mu też odmówić twórczych ambicji; publikowane w niewielkich - zważywszy na objętość - odstępach czasowych kolejne tomy składające się na cykl Paryskich pasaży (to jest: Paryskie pasaże. Opowieść o tajemnych przejściach, Raptularz końca wieku, Śmierć $w$ wodzie. Proza i Ostatni pasaż. Przepowieść o byciu byle-jakim ${ }^{1}$ ), a także samodzielne zbiory esejów, takie jak na przykład Książę bezdomny², ujawniają dążność pisarza do nakreślenia monumentalnej panoramy Paryża - stolicy XIX wieku. Sam autor tak pisze o projekcie stworzenia pasaży, formułując jednocześnie swój pisarki manifest, jak to określa - manifest „życiopisania”:

Pisać pasaże to ruszyć w drogę do krainy, której brak strony zewnętrznej, jak snom. I pisać je tak, jakbym chodzil, tak jak żyję, tak jak kocham, tak jak oddy-

- Artykuł ten jest poszerzoną wersją referatu wygłoszonego na V Konferencji Aksjologicznej Prawda $w$ literaturze zorganizowanej przez Katedrę Teorii Literatury Katolickiego Uniwersytetu Lubelskiego, Lublin 4-6 października 2007 r.

1 Kolejno: Gdańsk 1995, 1997, 1998, 2006.

${ }^{2}$ Lublin 1999. 
cham. Pisać pasaże - to ryzykować i nie zapominać o odpowiedzialności. To znaczy przede wszystkim: przywołać takie gatunki mowy, które odpowiedzialne ryzyko uniosą. Musiałem zatem wyzyskać swą wiedzę o technikach "dialogu" i pisarskie doświadczenie w perspektywie jedności pisania i życia ${ }^{3}$.

\section{Jednocześnie autor ostrzega:}

Z paryskich pasaży „czegoś ciekawego” o Francji i Paryżu dowiadujemy się tyle, ile [...] z Szumów, zlepów i ciqgów Mirona Białoszewskiego o Warszawie. Na przykład o tym, że przeleciał anioł śmierci, albo że łopianowe perspektywy otwierają bramę do raju. [...] „Można czegoś ciekawego o Francji się dowiedzieć”? Owszem ${ }^{4}$

Czego można dowiedzieć się o Paryżu z pasaży Rutkowskiego? Na ile prawdziwe jest jego paryskie doświadczenie i próby jego literackiego zapisu? Trudno odpowiedzieć na te pytania, skoro pasaże są przede wszystkim - jak podpowiada podtytuł pierwszego tomu - „opowieścią o tajemnych przejściach”, odkrywaniem nieznanego, opisywaniem niewysłowionego. Teksty oświetlające mroki miasta-labiryntu stają się pełnym zasadzek labiryntem interpretacyjnym, stąd artykuł niniejszy będzie przede wszystkim „próbą wyjścia”, refleksją nad konstrukcją pasażu jako formy reprezentacji i prawdy doświadczania przestrzeni miejskiej, czyli pytaniem o drogę, bądź oświetleniem kilku zaledwie ścieżek.

Prezentację Paryża, miasta, o którym, zdaje się, powiedziano już wszystko, Rutkowski rozpoczyna metodycznie, z zachowaniem chronologii. Pierwsze strony Paryskich pasaży to utrzymana w tonie właściwym historykowi sztuki czy idei narracja o historii francuskiej stolicy, jej dorastaniu do wielkości, o kolejnych projektach przebudowy miasta, problemach z kanalizacją, błocie za czasów Ludwika XVI i wreszcie o wiekopomnych reformach barona Haussmanna. Jednak już następne pasaże - choć bez trudu układają się miejscami w cykle tematyczne, o czym za chwilę - przynoszą rozproszone literackie obrazy przestrzeni miejskiej; wydawać by się mogło, że porozrzucane przypadkowo fragmenty nieistniejącej całości. Forma tekstu, jego nielinearność staje się $\mathrm{w}$ ten sposób ekwiwalentem sposobu doświadczania miasta przez podmiot, który zostaje wpisany w antropologiczną kategorię flâneura. Rutkowski odnajduje się w roli niespiesznego przechodnia: „Paryż do chodzenia jakby specjalnie został stworzony i nie znam innego miasta na świecie, po którym chodziłoby się równie ekstatycznie"6. Samotnie i bez celu (celem samym w sobie jest przecież przechadzka) przemierza paryskie dzielnice,

\footnotetext{
${ }^{3}$ K. Rutkowski, Śmierć $w$ wodzie..., s. 18.

4 Tamże, s. 19-20.

5 Taki tytuł nosi ostatni rozdział Opowieści o tajemnych przejściach.

${ }^{6}$ K. Rutkowski, Raptularz..., s. 136.
} 
percypując miasto, a symultanizm odbioru bodźców przekłada na kolażową kompozycję pasaży. Być może nawet więcej - pasaż staje się, używając słów Ryszarda Nycza, „epifaniczną strukturą ontologiczno-poznawczą" , narzędziem poznania miasta, medium doświadczenie przekazującym i jednocześnie je współkonstytuującym.

Kolejne ulice przynoszą nadmiar wrażeń, znaków domagających się przekucia w refleksję, zbyt wiele się dzieje i zbyt wieloma językami mówi Paryż, by doświadczenie miejskiej przechadzki przeformowane zostało w linearną narrację. Kolaż jako metafora epistemologiczna umożliwia uzyskanie efektu symultaniczności przez przywolanie odmiennych gatunków mowy, wchłania to, co niskie, gazetowe czy podsłuchane na ulicy, i to, co cytowane za mistrzami mowy. Refleksje o otwartej w 1889 roku na Polach Marsowych wielkiej Wystawie Powszechnej sąsiadują $\mathrm{z}$ informacją, że „3 lutego 1993 roku, w operze przy placu Bastylii odbyła się wielka feta na dwa tysiące osób z okazji trzydziestolecia działalności krawieckiej Yvesa Saint-Laurenta"8.

Artykulacja semiotycznego nadmiaru miejskiej przestrzeni, przerostu semiozy właściwego post-polis, wyznacza percepcyjną poetykę pasaży, bliską poetyce asocjacyjnej - nieskrępowana praca wyobraźni pobudzonej pełną przede wszystkim wzrokowych bodźców przechadzką kreuje ciągi literackich obrazów ${ }^{9}$. Jednocześnie fragmenty układają się niekiedy w wyraźne cykle tematyczne (zresztą są to często minipasaże wyznaczone graficznie i opatrzone tytułem, na przykład tom Paryskie pasaże został podzielony na „Pasaże uliczne”, „Pasaże podejrzane”, „Pasaże modne" i „Pasaże diabelskie”). Lecz nawet w obrębie tych stematyzowanych i graficznie wyodrębnionych cząstek uderza zaskakujące zestawienie motywów, juxtapozycja miejskich epizodów, którą legitymizuje właśnie prawo przypadkowości skojarzeń. W pierwszym tomie kolejne fragmenty składające się na cykl poświęcony malarstwu francuskiemu i odbywającym się aktualnie w Paryżu wystawom przerywa zainspirowana jedną $\mathrm{z}$ takich wizyt $\mathrm{w}$ muzeach refleksja nad pisarstwem Borgesa, co prowokuje przywołanie motywu labiryntu, poprzedzającego z kolei uwagi o Benjaminowskim ujęciu Paryża jako miasta pod ziemią. Pozwolę sobie zacytować początkowe zdania kolejnych akapitów tego fragmentu, oddające bieg myśli flâneura:

${ }^{7} \mathrm{R}$. Nycz, Literatura jako trop rzeczywistości. Poetyka epifanii $w$ nowoczesnej literaturze polskiej, Kraków 2001, s. 9.

${ }^{8}$ K. Rutkow ski, Paryskie pasaże..., s. 153.

9 O poetyce percepcyjnej w kontekście doświadczania przestrzeni miejskiej pisze E. Rybicka w książce Modernizowanie miasta. Zarys problematyki urbanistycznej $w$ nowoczesnej literaturze polskiej, Kraków 2003, szczególnie rozdział „Miejskie sensorium. Poetyka percepcyjna”, s. 100-180. 
Benjamin uważał, że Paryż powierzchniowy to miraż.

Kilka lat temu młodzieżówka urządzała sobie podchody i bitwy w podziemnych grotach, spuszczając się do Hadesu przez włazy studzienek.

Podziemne paryskie pasaże zaczęli kopać Rzymianie, później barbarzyńcy, potem prawi chrześcijanie.

Od XVI do XVIII wieku w podziemnych pasażach kwitła kontrabanda.

W mej domowej dzielnicy Le Marais znaleziono przed kilku laty rycerza śpiącego w zbroi.

Georges Proust zgromadzil w prywatnym muzeum ponad trzysta przedmiotów, urządzeń i narzędzi służących do wywoływania duchów [... ${ }^{10}$.

W następującym bezpośrednio po tej feerii myśli i obrazów fragmencie Rutkowski powraca do, zdawać by się mogło, porzuconego Borgesa, na zasadzie ciągu konotacyjnego, przywołując wspomnienie swojej wizyty w Bibliotece Narodowej. Cykle tematyczne łączy często pojedynczy obraz uruchamiający proces pracy pamięci, wyobraźni, twórczej kreacji wreszcie; nieznaczny szczegól, którego dostrzeżenie dopiero tłumaczy chaotyczną kompozycję - ekwiwalent chaosu miejskiego.

Strumień zdarzeń i - przede wszystkim - obrazów (literackie zapisy Paryża zdeterminowane są percepcją wizualną, postrzeganiem, stąd liczne refleksje poświęcone malarstwu francuskiemu, relacje $\mathrm{z}$ odwiedzanych wystaw itp.) stoi w opozycji do statyki, zamknięcia, aktu delimitacyjnego, natomiast pasaż przez otwartość formy pozwala na dopowiedzenie i urwanie $w$ pół zdania, zboczenie $z$ głównego miejskiego traktu ku peryferiom. Nie wyznacza granic wędrówki, nie zmienia właściwego flâneurowi dryfowania w dążenie ku, nie zatrzymuje aktu semiotyzowania przestrzeni. Delimitacja - także na płaszczyźnie kompozycji utworu literackiego - byłaby sprzeczna $\mathrm{z}$ ontologicznym statusem przechadzki miejskiej, flânerie. Kolaż i konstytuujący go element - fragment jako formy uprzywilejowane epistemologicznie mediatyzują złożony proces percypowania przestrzeni heterogenicznej, wielokrotnie zsemiotyzowanej. Wreszcie pozwalają na właściwą flâneurowi fascynację tłumem/miastem, ale bez konieczności partycypacji. Paryskiemu włóczędze, który rejestruje, a nie wartościuje, kolaż umożliwia zestawianie gatunków mowy, dochodzenie do prawdy poprzez dialog między tekstowymi interlokutorami. Jednocześnie cechy formalne pasażu jako kompozycji centonowej projektują określony styl odbioru.

Roma Sendyka tak pisze o pasażach Waltera Benjamina:

Stereometryczna konstrukcja Passagen-Werk domaga się podobnie wyprofilowanej stereometrycznej lektury: odpowiedniej dla „formy przestrzennej”, nielinearnej, pozbawionej obowiązującej zasady czasowego następstwa elementów.

${ }^{10}$ K. Rutkowski, Paryskie pasaże..., s. 133-134. 
[...] Pasaż staje się metaforą organizującą - formą, wokół której akumulują się społeczne, kulturowe, polityczne i naukowe problemy, sygnalizowane przez kolejne emblematy - wynalazki dziewiętnastowiecznej kultury masowej, „snu zbiorowości": ogrody zimowe, panoramy, fabryki, gabinety figur woskowych, kasyna. Praca Benjamina staje się tym sposobem aktem tekstualnej rekonstrukcji Paryża II Cesarstwa: przestrzeń miasta jest bowiem nieustannie semiotyzowana: znaki, słowa, gesty, przedmioty są niezmiennie funkcją znaczenia: jego eksponentem (metodą synekdochy, pars pro toto) lub przemieszczeniem (alegorią) ${ }^{11}$.

Synteza złożonej problematyki narastającej wokół hasła „nowoczesność", czy raczej modernité Baudelaire'a, i obrazów-emblematów, czy też fantazmatów kultury masowej, z pewnością charakteryzuje zwięźle także literacki zamysł Rutkowskiego - jego dążenie do opisania/przemierzenia/zdobycia Paryża-emblematu nowoczesności. Pasaż w jego ujęciu, podobnie jak u Benjamina, chce być wielką syntezą rzeczywistości. Oscylując między metaforą kolażu jako śmietnika rzeczywistości i kolażu jako pełnego pamiątek muzeum świata, którego już nie ma, dąży do bycia utopijną całością, choć formalnie skazany jest na fragmentaryczność.

$$
\text { * * * * }
$$

Podobieństwa $\mathrm{w}$ percypowaniu i literackiej reprezentacji doświadczenia przestrzeni miejskiej u Benjamina i Rutkowskiego są oczywiste. Obejmują nie tylko kwestię wyboru - i nazewnictwa zresztą również formy: pasażu, lecz również sposób selekcji materiału, podejmowaną problematykę. Paryskie pasaże na płaszczyźnie inwencyjnej są powtórzeniem tematów/problemów esencjalnych dla Benjaminowskiej refleksji - centralne miejsce w cyklu Rutkowskiego zajmują fragmenty poświęcone modzie, dandyzmowi, relacjom tłum-jednostka, towarom jako fetyszom, konsumpcji, fotografii, Wystawie Swiatowej i tak dalej. Wyliczenie podobieństw zajęłoby znacznie więcej miejsca, jednocześnie podjęcie tej komparatystycznej refleksji wymaga gruntowniejszych niż $w$ ramach jednego artykułu analiz. Ważne w kontekście mnie interesującym jest jednak zasygnalizowanie zjawiska intertekstualności.

Przedstawione dotychczas uwagi dotyczyły - można powiedzieć pierwszego, podstawowego, choć także niepozbawionego interpretacyjnych trudności i wymogu aktywności recepcyjnej odbiorcy, poziomu lektury i miały na celu przede wszystkim ukazanie złożonego aktu artykulacji procesu percepcji miasta. Już w takiej perspektywie literacki opis miasta implikuje wiele problemów teoretycznych, narastających wokół

11 R. Sendyka, Montaż rzeczywistości - o „Pasażach” Waltera Benjamina, „Wielogłos. Pismo Wydziału Polonistyki UJ” 2007, nr 1, s. 155-156. 
statusu podmiotu poznającego, perspektywy, jaką przyjmuje wobec przedstawianych przedmiotów, czynności interpretacyjnych, które podejmuje, takich jak selekcja elementów przestrzeni miejskiej, wreszcie wokół wyboru literackiej formy, aranżacji wybranych i zinterpretowanych przedmiotów w sposób najlepiej oddający akt percepcji, najbliższy literackiej prawdzie ${ }^{12}$.

Drugi poziom lektury, wprowadzający w perspektywę interpretacyjną zjawisko intertekstualności, znacznie odbiór Paryskich pasaży komplikuje. Obserwujemy bowiem w cyklu Rutkowskiego intertekstualne zabiegi przynajmniej trojakiego rodzaju, różne poziomy tekstu obejmujące. Po pierwsze, poszczególne zdania utkane są na zasadzie patchworku z cytatów, często niewyodrębnionych graficznie, kryptocytatów, aluzji czy parafraz. Zdania takie, jak „Z Le Marais idzie się do Domu Radia dwie godziny wzdłuż Sekwany. Nad samą wodą - dość wielką i nieczystą"13 czy „Bywało, że obłok fantazmatu przenosił mnie do pól malowanych zbożem rozmaitem, które okazywały się później pyszną skórą baszkirskich branek"14 nie tylko, co oczywiste, odsyłają do określonych literackich pierwowzorów, lecz również zdają się brać w nawias czy zgoła unieważniać próby pisarza najściślejszego oddania przeżycia miejskiej włóczęgi. Co więcej, przechodzę tutaj do kolejnej odmiany intertekstualnych gier Rutkowskiego, poszczególne pasaże - opisy Paryża niejednokrotnie imitują styl recenzji z książek podejmujących paryską tematykę lub są mikrobiografiami najsłynniejszych przedstawicieli modernistycznej bohemy - miejska topografia splata się więc miejscami z biografią intymną, lecz przecież nie z prywatną historią Rutkowskiego. W oczywisty sposób takie ujęcie tematu zbliża do analiz intertekstualności jako wyznacznika postmodernistycznego kolażu, którego elementarnymi jednostkami są klisza i cytat ${ }^{15}$, a który prowokuje podejrzenia o literacką grę nieroszczącą sobie aspiracji wobec referencjalności. Pasaże Rutkowskiego - i myślę, że są w tym względzie reprezentatywne dla szerszego korpusu nowoczesnych tekstów, które zdają się unieważniać interpretację nastawioną na aksjologię, a przynajmniej takie rozważania znacznie komplikują - byłyby zatem dobrze zrobioną zabawą konwencjami, fragmenty - niezobowiązującymi impresjami na temat tekstu paryskiego. $\mathrm{Z}$ pewnością - co nie ułatwia refleksji nad aksjologią - Paryskie pasaże potrafią uwieść czytelnika. Niezobowiązująca literacka kokieteria stoi

\footnotetext{
12 Por. E. Rybicka, op. cit.

${ }^{13}$ K. Rutk owski, Raptularz..., s. 312.

14 Tamże, s. 12.

${ }^{15} \mathrm{O}$ formie kolażu zob. R. Ny cz, O kolażu tekstowym. Zarys dziejów pojęcia, w: tegoż, Tekstowy świat. Poststrukturalizm a wiedza o literaturze, Kraków 2000, s. 247-292.
} 
jednak w sprzeczności z przywołanymi na początku deklaracjami autora o zgodności życia i pisania, odpowiedzialności eseistycznej.

Dysonans powstały między poetyką percepcyjną a poetyką intertekstualną może złagodzić - i stanowić pewne rozwiązanie interpretacyjne - przywołanie koncepcji miasta jako palimpsestu, wielowarstwowego tekstu domagającego się odczytania. Wielowarstwowego, gdyż noszącego ślady wielokrotnych zabiegów semiotyzacji, miasta już omówionego. Flâneur w takim ujęciu to nie tylko włóczęga i obserwator, ale też uważny czytelnik. Zmiana statusu podmiotu (włóczęga staje się egzegetą) nosi znamiona aktu etycznego. Rutkowski zastaje Paryż poddany już tekstowej rekonstrukcji i nie jest w stanie zlekceważyć śladów pozostawionych przez interpretatorów na tekście paryskim (określeniem „tekst paryski” posługuję się $\mathrm{w}$ znaczeniu, jakie nadał tekstowi petersburskiemu Władimir Toporow, definiując go jako „swego rodzaju heterogeniczny tekst, któremu przypisuje się pewien sens i na którego podstawie można zrekonstruować określony system znaków, realizowany w tekście"16). Rutkowski, aspirując do bycia uważnym czytelnikiem i adeptem sztuki interpretacji miasta, stosuje zabieg intertekstualny trzeciego rodzaju stylizuje własne doświadczenie włóczęgi na takie, jakiego zapis znalazł w dziełach poprzedników. Dlatego może zakończyć pasaże efektownymi formułami, jak: „Cioran to ja”17 lub „Z Baudelaire'em spotykam się stale"18. Są to poniekąd wypowiedzi postulatywne i tłumaczące Bachtinowskie fascynacje autora, jego dążność do polifonii. Maskarady Rutkowskiego, jego stylizacje na głównych bohaterów tekstu paryskiego dandysa, flâneura, włóczęgę, można traktować jako podejmowanie coraz to nowych prób werbalizacji prawdy, „wypróbowywanie” sposobów artykulacji miasta w poszukiwaniu tego najbardziej skutecznego. $\mathrm{Na}$ innym poziomie - cytatu, kryptocytatu, aluzji, czy wyższym - recenzji i streszczenia, czyli poniekąd metaopisu, byłby to zabieg polegający na wprowadzeniu do pasaży wewnętrznej dialogiczności, byłoby to poszukiwanie prawdy jako stanowiska uzgodnionego w dyskusji powołanych do tekstowego życia interlokutorów, uświadamianie złożoności drogi pomiędzy obiektywną prawdą przedstawienia a literackim konstruktem - jak pisze Ryszard Nycz:

Badanie intertekstualności [...] nie wyprowadza nas oczywiście poza ów poziom mediacyjnych reprezentacji [...]. Nie pozwala zatem odpowiadać na pytanie o obiektywną prawdę przedstawienia i realne istnienie jego przedmiotu. Umożliwia jednakże [...] rozpoznanie językowych procedur i dyskursywnych strategii,

${ }^{16}$ W. Toporow, Miasto i mit, przeł. B. Żyłko, Gdańsk 2000, s. 73.

${ }^{17}$ K. Rutkowski, Raptularz..., s. 232.

18 Tamże, s. 242. 
które slużą wytworzeniu i uprawomocnieniu takiego efektu w przekonaniu odbiorcy ${ }^{19}$.

Rutkowski demaskuje właściwe literaturze zabiegi mediatyzacji za pomocą intertekstualności, między innymi przez technikę montażu prefabrykatów, która stać się ma demontażem zapośredniczeń, dyskursywnych strategii, a przynajmniej ich obnażeniem, przez wycięcie cytatu $\mathrm{z}$ pierwotnego kontekstu i rekontekstualizację, która w kolażu jest nierozdzielna $\mathrm{z}$ resemantyzacją. Zabieg resemantyzacji nie zostaje jednak w Paryskich pasażach przeprowadzony do końca.

$$
\text { * * * }
$$

Fakt, że dekontekstualizację fragmentów-prefabrykatów budujących Paryskie pasaże Rutkowski przeprowadził z pełną poszanowania dla pierwotnego ich sąsiedztwa semantycznego delikatnością, wyznacza zakres następnego poziomu odbioru. Dodatkowo przemawia za odróżnieniem nawiązań intertekstualnych $\mathrm{w}$ omawianych utworach od postmodernistycznej gry konwencjami. Wyróżnikiem tym będzie odmienna funkcja obecnego poprzez cytat hipotekstu. U Rutkowskiego ma on przede wszystkim potwierdzić, uprawomocnić, uczynić prawdziwym, a więc również nacechować aksjologicznie wywód eseisty. Praktyka cytowania przypomina przywoływanie słowa autorytatywnego, Bachtinowskiego „słowa zastanego"20, zabieg alegacji, który Michał Głowiński określa jako:

[...] wszelkie odwolania tekstowe, nie lączące się z żywiołem dialogiczności, takie, w których cytat czy aluzja nie tylko nie staje się czynnikiem wielogłosowości, ale - przeciwnie - utwierdza jednoglosowość. Dzieje się tak wówczas, gdy przywołany tekst traktowany jest jako autorytatywny, obowiązujący, a priori słuszny i wartościowy; w konsekwencji tekst cytujący zostaje podporządkowany tekstowi cytowanemu. Pierwszy ma się stać autorytatywny za sprawą autorytatywności drugiego 21 .

W przypadku Rutkowskiego dialogiczność pojmowana jako zestawienie cytatów-głosów na temat tekstu paryskiego nie wyklucza alegacji. Funkcję autorytetu pełni z pewnością księga pasaży Benjamina. Dzięki swojemu literackiemu statusowi dzieła legendarnego, niejako „a priori słusznego i wartościowego”, legitymizuje prawdziwość doświadczenia

${ }^{19} \mathrm{R}$. Nycz, Intertekstualność i jej zakresy: teksty, gatunki, światy, w: tego ż, Tekstowy świat. Poststrukturalizm a wiedza o literaturze, Kraków 2000, s. 96.

20 M. Bachtin, Stowo $w$ powieści, w: tegoż, Problemy literatury $i$ estetyki, tłum. W. Grajewski, Warszawa 1982, s. 183.

${ }^{21}$ M. Głowiński, O intertekstualności, w: tegoż, Prace wybrane, red. R. Nycz, t. 5: Intertekstualność, groteska, parabola. Szkice ogólne i interpretacje, Kraków 2000, s. 23. 
miejskiej włóczęgi Rutkowskiego. Akt repetycji i imitacji staje się aktem nobilitacji, nabierania przez tekst cytujący (hipertekst) autorytatywności. Nie bez znaczenia jest z pewnością także atrakcyjność dzieła Benjamina w kontekście komunikacji literackiej, swoista moda literacka. Wybór pasażu jako medium przekazującego obrazy paryskie oraz powtórzenie motywów stanowiących o popularności twórczości Benjamina bylby $\mathrm{w}$ takim ujęciu gwarantem recepcyjnego powodzenia cyklu Rutkowskiego, taktyką komunikacyjną.

Choć Benjamin odgrywa tak w kompozycji, jak i w treści pasaży Rutkowskiego rolę nadrzędną, autorytetu najwyższego, Paryskie pasaże noszą ślady innych jeszcze źródeł inspiracji. Sam autor wyznaje:

Rozgrywam pisanie na cztery ręce, współmyśląco: na przykład ze Stachurą, z Bobkowskim, z Bialoszewskim, z Benjaminem i z Bachtinem, Barthes'em i Hauptem. Wspólmyślę, więc wspótpiszę. A współpiszę, bo jestem cały odmieniony przez wielką i piękną silęę2.

\section{I jeszcze jedno wyznanie:}

Moje szukanie wyklucza techniki, którymi posługiwałem się jeszcze przed rokiem: na przykład montaż różnych głosów, pośród których - w odbiciach - rozbrzmiewał głos własny, ale ukryty i w gruncie rzeczy niezbyt pewny swego, zawieszony $[\ldots]^{23}$.

Rutkowski dopuszcza, a nawet waloryzuje, za cenę dochodzenia do prawdy, żywioł dialogiczności, zestawiania, oświetlania nowym dla zapożyczonych fragmentów kontekstem. Jednocześnie polifonia przechodzi w zgodność cytatów, gdy Rutkowski przywołuje ustanowione na mocy swoistej „licencji poetyckiej” autorytety, których zestaw ogranicza się do niezaprzeczalnych znawców tajemnic Paryża, takich jak Benjamin czy Baudelaire, ale i do rodzimych klasyków tematyki miejskiej - Białoszewski i obrazów literackiej wędrówki - Stachura.

Możliwość uznania tak przeprowadzonego zabiegu alegacji za dopuszczający element tekstualnej gry z pierwowzorem (podjęciem gry jest przecież już samo, dystansujące się do tradycji, zestawienie autorów) jest z pewnością polemiczna wobec ujęcia Głowińskiego, choć przecież utrzymany zostaje konstytutywny dla alegacji wyróżnik - jednogłosowość. (Wszak tak odmienni twórcy, jak Benjamin czy Białoszewski, mówią jednym głosem, gdy przedmiotem dyskusji jest tekst miejski). Wydaje się, że takim postawieniem problemu powracamy do teoretycznoliterackich źródeł alegacji, do Giselle Mathieu-Castellani, która wprowadziła termin allégation w kontekście renesansowej literatury, określając tym

${ }^{22}$ K. Rutkowski, Smierć $w$ wodzie..., s. 230.

23 Tamże, s. 224. 
mianem nawiązania antyczne wyrosłe $\mathrm{z}$ odrodzeniowego uniwersalizmu kulturowego i go potwierdzające ${ }^{24}$. Głowiński, adaptując francuski termin, nadał mu jednocześnie znaczenie pejoratywne. Praktycznie rzecz ujmując, przejął samo określenie, używając go następnie do opisania zupełnie odmiennego zjawiska, takiego mianowicie, jakie streszcza się w zdaniach:

[...] przejawem alegacji, nie zaś intertekstualności, są np. odwołania do Marksa lub Engelsa w pismach marksisty, uznającego bezwzględną autorytatywność twórców doktryny [...]. W ogromnej większości przypadków alegacja to przywoływanie instytucjonalnie uwarunkowane. Nie będzie zapewne przesadą, gdy się powie, że współcześnie jest ona przede wszystkim domeną wypowiedzi doktrynalnych i propagandowych, jeśli nie wszelkich, to przynajmniej pewnego typu. [...]. Oczywiście alegacje występować mogą także w literaturze; dzieje się tak wówczas, gdy podejmuje ona zadania propagandowe (np. we wszelkiego rodzaju pisarstwie tendencyjnym). Nie są jednak jej właściwą domeną, tę bowiem stanowi intertekstualność 25 .

Głowiński, wyprowadzając zjawisko alegacji poza ramy literatury dawnej, paradoksalnie, zawęził, zamknął $w$ znacznie sztywniejszych i niechętnie przekraczanych granicach literatury tendencyjnej. Nie przewidział ${ }^{26}$ potencjału zjawiska, pozwalającego alegacji zaistnieć $w$ literaturze najnowszej, gdy przedmiotem odwołania nie są ani antyczne, ani tendencyjne teksty. Gdy status ksiąg świętych zajęły księgi-legendy, a miejsce „przywoływania instytucjonalnie uwarunkowanego" przywoływanie dzieł - mówiąc językiem dekonstrukcji - pisanych idiomem przeciw instytucji. Alegacja w tym sensie, jaki próbuję jej tu nadać, byłaby więc bliższa allégation niż rozważaniom Głowińskiego.

Pozwalałby też na zaistnienie $w$ polu zainteresowania literaturą najnowszą pytania o literacką prawdę. Pierwowzory użyczające swej autorytatywności Paryskim pasażom wspomagają bowiem wszystkie opisane dotychczas próby zbliżenia się do prawdy literackiej artykulacji doświadczenia. Cytowanie literackiego autorytetu potwierdza obserwacje flâneura, nacechowuje je aksjologicznie, ale też zapośrednicza, doświadczenie staje się utekstowione, przefiltrowane przez tekst autorytatywny, który narzuca sposób percepcji rzeczywistości oraz jej wartościowanie. $\mathrm{Na}$ ile świat eseju jest światem jego podmiotu, a na ile doświadczaniem „zapożyczonym”, „powtórzonym”? Czy może z zapośredniczenia tworzy się jeszcze inna jakość, prawda mediacji dwóch, a nawet więcej, podmio-

${ }^{24} \mathrm{G}$. Mathieu-Castellani, Intertextualité et allusion. Le régime allusive chez Ronsard, „Litterature” 1984, nr 55, passim.

${ }^{25}$ M. Głowiński, op. cit., s. 23-24.

26 Pierwodruk artykułu O intertekstualności w „Pamiętniku Literackim” 1980, z. 4. 
tów? I wreszcie, o tej perspektywie nie można zapominać, na ile prawda, do której przez przywołanie autorytetów chce przekonać Rutkowski, jest prawdą oczekiwaną w odbiorze czytelniczym, a autor - sprytnym dostarczycielem pożądanego towaru?

$$
* * * *
$$

Rutkowski dostarcza towar w atrakcyjnym opakowaniu. Była już mowa o wykorzystaniu cieszących się czytelniczym powodzeniem tematów, przywołaniu całego, Benjaminowskiego katalogu dziewiętnastowiecznych emblematów miasta. Chwytem najskuteczniejszym jest jednak płynne przechodzenie - używam tu terminologii Elżbiety Rybickiej ${ }^{27}$ - z poetyki percepcyjnej ku poetyce fantasmagorycznej, czego najlepszą realizacją jest stałe przywoływanie mitu Paryża. Już decyzja rozpoczęcia całego cyklu Paryskich pasaży od fragmentu poświęconego fenomenowi Tajemnic Paryża Eugeniusza Sue - jednego z twórców literackiego mitu miasta - zdaje się tę strategię zapowiadać. Umacnia ją wybór autorytetów - odwołania do Baudelaire’a czy Benjamina są bezpośrednim odwołaniem do paryskiego mitu i jednocześnie jego umacnianiem - Rutkowski dodaje do rozległej już literackiej konstrukcji własne cegiełki. Nie tylko poświęca obszerne fragmenty opisom życia paryskiej bohemy, ulubionym przez panegirystów Paryża kloszardom, włóczęgom, prostytutkom, koncepcji miasta ukrytego $\mathrm{w}$ podziemiach $\mathrm{i}$ tak dalej (znów repertuar jest znaczenie bogatszy, a pasaże zbyt obszerne i pojemne, by poświęcić miejsce enumeracji), ale i szuka własnych miejsc przejścia, które - zgodnie $\mathrm{z}$ konstrukcją tak realnych, jak i literackich pasaży - łączyłyby publiczne $\mathrm{z}$ prywatnym, wnętrze $\mathrm{z}$ zewnętrzem oraz realistyczne, cielesne $\mathrm{z}$ fantasmagorycznym, duchowym:

Różne mogą być wyprawy do miasta. Najlepiej nocne. Bo wtedy dwa miasta przenikają się wzajem, wyzierają z ciemności ułomkami, migają jak upiory w lustrzanym odbiciu: pamięci? deszczu? snu? Dwa obrazy łączą się w jednym, nie tracąc w podwojeniu na jedności. Wędrowiec przemyka - Białoszewski powiada: „lata” po ulicach. Nasłuchuje, węszy i widzi nie tylko okiem cielesnym, ale i okiem duchowym ${ }^{28}$.

Zresztą czynności mitotwórcze Rutkowskiego obejmują znacznie szersze partie tekstu - ujęcie Paryża jako soczewki skupiającej w sobie to, co europejskie, służy mu na mocy synekdochy (miasto - świat) jako pretekst do wyrażania sądów - $\mathrm{z}$ ducha Benjaminowskich - o zepsuciu

27 E. Rybicka, op. cit., s. 100-228, passim.

${ }^{28}$ K. Rutkowski, Raptularz..., s. 42. 
społeczeństw kapitalistycznych, demokratycznych, o teatralizacji zachowań, przesycie konsumpcyjnym, wulgaryzacji tłumu i innych negatywnych skutkach zwycięstwa domu towarowego nad dziewiętnastowiecznym pasażem. W jednym $\mathrm{z}$ fragmentów czytamy:

Jak Rosję i świat cały widać z Paryża? Tutaj można zobaczyć i poczuć, jak tradycje Europy zwanej Zachodnią trzeszczą i pękają w szwach, jak przemija skóra świata i pojęcia pustoszeją, zioną wklęsłym krzykiem niczym usta na porozwieszanych w Centre Pompidou obrazach Francisa Bacona ${ }^{29}$.

Ujęcie miasta-uniwersum zostaje wzbogacone $u$ Rutkowskiego o sztafaż apokaliptyczny. Paryż za Słowackim i w zgodzie z topiką miast opisywanych przez emigrantów zyskuje miano „Nowej Sodomy”, a jeden $\mathrm{z}$ tomów cyklu nosi nazwę, przypomnę, Raptularz końca wieku. Mit Apokalipsy, często bardziej precyzyjnie - jako mit millenarystyczny (nie zapominajmy, że Paryskie pasaże, oprócz ostatniego, odmiennego w stylistyce tomu, pisane były w latach dziewięćdziesiątych ubiegłego wieku, gdy tematyka milenijna była nad wyraz popularna) - splata się z mitologia miejską, wpływa na stylistykę opisów Paryża, czyni z miasta pretekst do rozważań quasi-historiozoficznych, czasem aktualnych, felietonowych uwag na temat bieżącego życia politycznego we Francji, chwilami niebezpiecznie degradując mit paryski, deprecjonując go uwikłaniem w doraźność; częściej - nobilitując miasto, nadając mu rangę stolicy świata. Calość - dziwna symbioza literackiego efektu symultaniczności będącego ekwiwalentem doznań flâneura, pragnienia opisania wszystkiego, co dotyczy miasta (służy temu nawet przywoływanie dokładnych badań naukowych i statystyk), oraz utrzymanych w poetyce fantasmagorycznej poszukiwań tajemnych przejść, mitycznego Paryża i topiki apokaliptycznej - daje interesujący efekt kompozycyjny, napędza rozgrywającą się na tylu już wspomnianych poziomach grę literacką. I budzi podejrzenie zastosowania prostego chwytu - odwołania się do tęsknoty za mitem odbiorców, do ich potocznej, niewymagającej poszerzenia, wiedzy o Paryżu jako stolicy XIX wieku i ich pragnienia znalezienia tekstualnej sugestii istnienia tajemnicy, miasta nieznanego, którego będą odkrywcami - tu grę literacką konstytuuje obietnica nagrody, tajemnica i poszukiwanie. Rutkowski budzi więc podejrzenia o brak aspiracji, by przełamać horyzont oczekiwań czytelniczych, klisz i stereotypów, z jakich zbudowany jest ich zbiorowy, pop-kulturowy tekst paryski. Czynności powtarzające i współkonstytuujące mit miejski byłyby więc kolejnym elementem gry intertekstualnej jako taktyki recepcyjnej.

29 Tamże, s. 329. 
Nakierowanie na odbiorcę jest immanentną cechą każdej gry literackiej, w przypadku Paryskich pasaży natomiast rola czytelnika okazuje się niezwykle istotna. Rutkowski - flâneur końca XX wieku i uważny czytelnik, być może nawet hermeneuta miasta, zastając tekst pełen śladów poprzedników-egzegetów, może zlekceważyć narosłe narracje, sprzeniewierzając się $\mathrm{w}$ ten sposób odpowiedzialności procesu interpretacyjnego, lub zostawić na palimpseście ślad własnej pracy w dochodzeniu do prawdy. Może więc dopisać kolejne przypisy, uwagi na marginesie lektury miasta-tekstu. Sam Rutkowski tak to ujmuje, pisząc o Białoszewskim:

Wędrowiec istnieje i się toczy tylko i wyłącznie pośród mowy Miasta, szepczących zaułków i chrapiących podwórek zakreślających uniwersum - pole moźliwej rozmowy. Wędrowiec „lata” po mieście, ale Miasto przekracza Wędrowca: pojawil się w nim nagle, by wsłuchiwać się i odczytywać przesłania, i opuścil je nagle, pozostawiając lekturę w miejscu równie przypadkowym, jak było na początku ${ }^{30}$.

Nigdy niekończący się egzegetyczny proces czytania i jednocześnie pisania miasta pozostaje niedokończony, tak jak pasaże Benjamina i tak jak hipotetyczna, zaginiona księgi miasta, które już nie istnieje, a którego ślady podlegają ciągłej reinterpretacji przez ponowne odczytania ocalałych fragmentów. Rutkowski do takich fragmentów w swoich Pary. skich pasażach konstruuje przypisy. Jego egzegeza śladów jest jednocześnie aktem aksjologicznym i nadającym sens literackiej grze.

Ryszard Nycz, analizując formę literackiego kolażu, stwierdza:

Komentarz jest aspektem użytej metody. Poetyka kolażu, opierająca się często na metonimicznym rozwinięciu wyjściowych składników, nie zezwala z zasady na tematyzację generalnego projektu integracji tekstu ani na wprowadzenie jednoznacznych instrukcji odczytania globalnego sensu. Uogólnienie informacji o znaczeniu i strukturze całego tekstu domaga się dopiero rozumiejącej - a przy tym zawsze hipotetycznej i niepelnej - interpretacji ${ }^{31}$.

Czytelnik Paryskich pasaży otrzymuje nie tylko zaproszenie do intelektualnej przechadzki śladami autora, lecz również do gry w dotarcie do prawdy - prawdy symultanicznego, nielinearnego i niepodlegającego rygorom formalnym doświadczenia życia-włóczęgi. Jedyną regułą tej gry jest bliski Baudelaire'owi heroizm życia w epoce modernité, w przypadku czytelnika Rutkowskiego polegający na odnalezieniu się $\mathrm{w}$ natłoku in-

30 Tamże, s. 45.

31 R. Nycz, O kolażu tekstowym. Zarys dziejów pojęcia, s. 256. 
formacji, obronie przed pokusą wypowiedzenia/przeżycia wszystkiego, dążnością do spisu powszechnego, obejrzenia wszystkich witryn w pasażach. Ponownie zacytuję Tekstowy świat, tym razem fragment analiz kolażowej prozy Buczkowskiego:

Niemożność uzgodnienia rozbieżności sekwencji znaczeniowych, ostatecznego uporządkowania i scalenia tekstu, odslania ostatni, mityczny wymiar kolaży Buczkowskiego; jako uklady elementów znaczących trzeciego systemu semiologicznego otwierają się one na nieograniczony i nieprzewidywalny w całości proces czytania. Kompetencja oraz aktualna odmiana czynności recepcyjnych pozwala odbiorcy wybrać jakiś wariant lektury, łączący się z innymi możliwymi sposobami interpretacji w hipotezie Księgi, w stosunku do której każdy tekst jest fragmentem, „notatkami do Dzieła”, a lektura - niepełna i niewystarczająca ${ }^{32}$.

Kolaż postuluje wybór strategii lekturowej, przenosi na czytelnika odpowiedzialność wynikającą z dokonania aktu selekcji, czyli wartościowania; z przyjęcia na siebie obowiązku samodzielności i odpowiedzialności za akt interpretacji.

32 Tamże, s. 262. 